\begin{tabular}{|c|}
\hline Studia Theologica Varsaviensia \\
UKSW \\
$1 / 2021$ \\
\hline
\end{tabular}

Piotr Drzewiecki ${ }^{1}$

\title{
E-SPORT W PERSPEKTYWIE TEOLOGII MEDIÓW I KOMUNIKACJI
}

\section{INTRODUKCJA}

Sport elektroniczny jest coraz częściej uznawany za równoprawną formę rywalizacji, tak jak ma to miejsce w przypadku innych dyscyplin rozgrywanych w formie rzeczywistej np. na boisku piłkarskim czy korcie tenisowym. Spełnia istotne kryteria współczesnych definicji sportu: stanowi formę zabawy, czyli rozrywki połączonej z walorami edukacyjnymi, jest zorganizowany i ustalony przepisami gry, polega na współzawodnictwie, wymaga wcześniejszego treningu, a nie przypadkowych umiejętności, posiada określone audytorium, cechuje go wsparcie instytucjonalne w postaci klubów czy lig². Powinien zawierać również element wysiłku fizycznego, co w przypadku e-sportu budziło na początku kontrowersje. Współcześnie dostrzega się obecność i tego istotnego aspektu, szeroko pojmując fizyczność

${ }^{1}$ Piotr Drzewiecki, medioznawca, dr hab. teologii środków społecznego przekazu, prof. uczelni, wykładowca w Instytucie Edukacji Medialnej i Dziennikarstwa na Wydziale Teologicznym Uniwersytetu Kardynała Stefana Wyszyńskiego w Warszawie, specjalista w zakresie edukacji medialnej.

2 A. Guttmann, From ritual to record: The nature of modern sports, New York 2004; B. Suits, The Elements of Sport, w: Ethics in Sport, red. W.J. Morgan, Champaign 2007, s. 9-19. 


\section{E-SPORTS IN THE PERSPECTIVE OF MEDIA AND COMMUNICATION THEOLOGY}

\section{INTRODUCTION}

e-Sports are increasingly recognised as an equal form of competition, as is the case with other disciplines played in real life, e.g. on a football pitch or a tennis court. They meet the essential criteria of contemporary definitions of sport: they are a form of fun, i.e. entertainment combined with educational values, they are organised and determined by the rules of the game, they involve competition, they require prior training rather than random skills, they have a specific audience, and they are characterised by institutional support in the form of clubs or leagues. ${ }^{2}$ e-Sports should also include an element of physical exertion, which was controversial in the beginning. Nowadays, the presence of this important aspect is recognised as well, with sports physicality in a broad sense, taking

1 Piotr Drzewiecki, media expert, $\mathrm{PhD}$ in theology of social media, university professor, lecturer at the Institute of Media Education and Journalism at the Faculty of Theology of the Cardinal Stefan Wyszyński University in Warsaw, specialist in media education.

2 A. Guttmann, From Ritual to Record: The Nature of Modern Sports, New York 2004; B. Suits, The Elements of Sport, in: Ethics in Sport, ed. W.J. Morgan, Champaign 2007, pp. 9-19. 
sportową, uwzględniając zdolności manualne graczy i koncentrację umysłową, co wynika $\mathrm{z}$ codziennego $\mathrm{i}$ intensywnego treningu $\mathrm{u}^{3}$.

E-sport stał się fenomenem kulturowym, społecznym i gospodarczym. Coraz większą popularność zyskują zespołowe turnieje graczy wideo, czego przykładem jest organizowany w Katowicach doroczny Intel Extreme Masters, aktywizujący nie tylko branżę sportową i rozrywkową, lecz także turystyczną ${ }^{4}$. Elektroniczna rywalizacja jest wykorzystywana także jako narzędzie rozwoju medycyny, wojskowości, edukacji, marketingu, treningu personalnego i sztuki ${ }^{5}$. Profesjonalni gracze komputerowi są coraz częściej postrzegani jako nowa grupa zawodowa, a nie tylko społeczność hobbystów ${ }^{6}$. Podejmuje się dyskusje o w zakresie zatrudniania zawodników e-sportowych ${ }^{7}$. Organizacje sportowe dokonują przeobrażeń pod wpływem rozwoju e-sportu. Stają się aktywnym podmiotem w branży, organizując własne drużyny elektroniczne i rozgrywki meczowe ${ }^{8}$. Kluby piłkarskie inwestują w sekcje e-sportowe, czego przykładem jest turniej gry FIFA Legii Warszawa i Electronic Sports League. Polska zyskuje e-sportową sławę nie tylko za sprawą organizacji rozgrywek, lecz także zespołowej rywalizacji. Przede wszystkim w Counter Strike: Global Offensive - pięciokrotne mistrzostwo świata

${ }_{3}$ M. Witkowska, Funkcjonowanie wykonawcze profesjonalnych graczy komputerowych, „Homo Ludens” 2016, t. 9, nr 1, s. 243-258; S.E. Jenny, R.D. Manning, M.C. Keiper, T.W. Olrich, Virtual(ly) athletes: where eSports fit within the definition of "Sport”, „Quest” 2017, t. 69, nr 1, s. 1-18.

${ }^{4}$ R. Rouba, Realny sukces wirtualnego sportu-Intel Extreme Masters-Katowice, „Przegląd Nauk Ekonomicznych” 2017, nr 27, s. 301-312.

${ }^{5}$ K. Jędrasiak, Gracz jako model uczestnika wspótczesnej kultury, rozprawa doktorska, Uniwersytet Lódzki, Lódź 2017.

${ }^{6}$ M. Myślicki, Przepraszam, czy to sport? O profesjonalizacji e-sportów i jej skutkach, „Dziennikarstwo i Media” 2015, t. 6, s. 213-226.

7 M. Passon, M. Różyczka, Wybrane problemy związane ze statusem zawodnika e-sportowego w świetle zbiorowego prawa pracy w Polsce, „Internetowy Przegląd Prawniczy TBSP UJ" 2018, t. 43, nr 3, s. 85-101.

${ }^{8}$ P. Kuźbik, E-sportjako kreator nowych warunków organizacyjnych w zmiennym i dynamicznym otoczeniu, „Ekonomiczne Problemy Usług” 2018, t. 131, nr 2, s. 211-220. 
into account players' manual skills and mental concentration, which results from daily and intensive practice. ${ }^{3}$

e-Sports has become a cultural, social and economic phenomenon. Team-based tournaments for video gamers are gaining in popularity, an example of which is the annual Intel Extreme Masters organised in Katowice, which activates not only the sports and entertainment industry, but also tourism. ${ }^{4}$ Electronic competition is also used as a tool for the development of medicine, the military sector, education, marketing, personal training and the arts. ${ }^{5}$ Professional computer gamers are increasingly seen as a new professional group rather than just a community of hobbyists. ${ }^{6}$ Discussions are being held about the recruitment of e-Sports players. ${ }^{7}$ Sports organisations are transforming under the influence of the development of e-Sports. They are becoming an active player in the industry, organising their own electronic teams and match competitions. ${ }^{8}$ Football clubs are investing in e-Sports sections, such as the FIFA game tournament

3 M. Witkowska, Funkcjonowanie wykonawcze profesjonalnych graczy komputerowych [Executive functioning of Pro gamers], „Homo Ludens” 2016, vol. 9, no. 1, pp. 243-258; S.E. Jenny, R.D. Manning, M.C. Keiper, T.W. Olrich, Virtual(ly) athletes: where eSports fit within the definition of ,Sport", „Quest” 2017, vol. 69, no. 1 , pp. 1-18.

4 R. Rouba, Realny sukces wirtualnego sportu-Intel Extreme Masters-Katowice [The real success of virtual sport - Intel Extreme Masters-Katowice], Review of Economic Sciences 2017, no. 27, pp. 301-312.

5 K. Jędrasiak, Gracz jako model uczestnika współczesnej kultury [A gamer as a model participant in the contemporary culture], $\mathrm{PhD}$ dissertation, University of Lodz, Lodz 2017.

6 M. Myślicki, Przepraszam, czy to sport? O profesjonalizacji e-sportów i jej skutkach [Excuse me, is it sport? On the professionalisation of e-Sports and its effects], Journalism and Media 2015, vol. 6, pp. 213-226 „Dziennikarstwo i Media” 2015, t. 6, s. 213-226.

7 M. Passon, M. Różyczka, Wybrane problemy związane ze statusem zawodnika e-sportowego $w$ świetle zbiorowego prawa pracy $w$ Polsce [Selected problems related to the status of an e-Sports player in the light of collective labour law in Poland], TBSP UJ Internet Legal Review 2018, vol. 43, no. 3, pp. 85-101.

8 P. Kuźbik, E-sport jako kreator nowych warunków organizacyjnych w zmiennym i dynamicznym otoczeniu [e-Sports as a creator of new organisational conditions in 
drużyny Virtus.pro ${ }^{9}$. E-sport sprzyja tworzeniu nowych modeli biznesowych, poszerza tradycyjne formy rozrywki medialnej, w większym stopniu angażuje audytoria. Skłania do tworzenia własnych treści medialnych związanych z rywalizacją lub do podjęcia decyzji o zostaniu graczem ${ }^{10}$. Dociekania obejmują nie tylko sam fenomen e-sportowy, lecz także zmierzają do ustalenia, kim współcześnie stała się osoba gracza komputerowego i jaką wspólnotę - nie tylko sportową - tworzy on z innymi. Gracz coraz częściej jest rozumiany jako specyficzny typ uczestnika kultury. Powstaje wokół niego nowa refleksja antropologiczno-kulturowa, nazywana ludologią czy też groznawstwem. Gracze komputerowi na tle zmian technologicznych XXI wieku coraz rzadziej są postrzegani jednostkowo, a częściej jako osoby tworzące rzeczywistą społeczność. Próbuje się tworzyć swoistą typologię grających, ukazującą ich znaczące zróżnicowanie: typ społecznika, zdobywcy, odkrywcy lub zabójcy ${ }^{11}$.

Uzasadnionym jest zatem postawienie pytania o teologiczne aspekty e-sportu. Interesuje nas przede wszystkim jako zjawisko medialne i komunikacyjne, stąd zawężenie kwerendy i analizy do teologii mediów i komunikacji. Szerokie opracowanie z zakresu teologii sportu wydaje się bowiem przedsięwzięciem znacznie przekraczającym ramy artykułu, bardziej skłaniającym do podjęcia badań monograficznych. Celem analizy jest zatem ustalenie nauki Kościoła katolickiego o mediach i komunikacji na temat e-sportu, jak również wskazanie na nie podjęte jeszcze w Magisterium zagadnienia problemowe dotyczące zespołowych rozgrywek gier wideo w rzeczywistości wirtualnej.

9 M. Ziętarski, Rosnace znaczenie przemystu kreatywnego w Polsce na przykładzie rynku gier wideo, „Catallaxy” 2019, t. 4, nr 1, s. 73-82.

10 M. Felczak, Ekran i igrzyska: zwiąki gier z biznesem i sport elektroniczny, „Kultura Współczesna” 2016, t. 90, nr 2, s. 69-77.

11 M. Surówka, Społeczność graczy komputerowych w obliczu zmian technologicznych XXI w., „Com.press” 2019, t. 2, nr 2, s. 40-58. 
between Legia Warszawa and the Electronic Sports League. Poland is having a name for e-Sports not only through the organisation of competitions but also through team rivalry. Primarily in Counter Strike: Global Offensive - five-time world champion Virtus.pro team. ${ }^{9}$ E-sports fosters new business models, expands traditional forms of media entertainment, and engages audiences to a greater extent. It encourages people to create their own competitive media content or to decide to become a gamer. ${ }^{10}$ Not only does the study explore the e-Sports phenomenon itself, but it also seeks to determine who the computer gamer is today and what kind of community - not just a sporting one - he or she forms with others. The gamer is increasingly understood as a specific type of the participant in culture. S/he is the subject of a new anthropological and cultural reflection, called game studies, also known as ludology. With the technological changes of the twenty-first century as a background, computer gamers are less and less often perceived as individuals, and more often as people who form a real community. There is even a peculiar typology of players, showing their significant differentiation: Socializers, Explorers, Achievers and Killers. ${ }^{11}$

It is therefore legitimate to ask the question about the theological aspects of e-Sports. We are primarily interested in it as a media and communication phenomenon, hence the narrowing of the search and analysis to the media and communication theology. An extensive

a fluctuating and dynamic environment], „Economic Problems of Services” 2018, vol. 131, no. 2, pp. 211-220.

9 M. Ziętarski, Rosnace znaczenie przemystu kreatywnego w Polsce na przykładzie rynku gier wideo [The growing importance of the creative industry in Poland on the example of the video game market], „Catallaxy” 2019, vol. 4, no. 1, pp. 73-82.

10 M. Felczak, Ekran i igrzyska: związi gier z biznesem i sport elektroniczny [The screen and the games: the relationship between games and business and electronic sport], „Kultura Współczesna” [Contemporary Culture] 2016, vol. 90, no. 2, pp. 69-77.

11 M. Surówka, Społeczność graczy komputerowych w obliczu zmian technologicznych XXI [The computer gaming community under the technological changes of the 21st century], Com.press 2019, vol. 2, no. 2, pp. 40-58. 


\section{MATERIALY I METODY}

Źródłem naszych badań jest przede wszystkim nauczanie Kościoła katolickiego o mediach i komunikacji, w szczególności dotyczące zagadnień temat wirtualnej rzeczywistości, internetu i mediów społecznościowych ${ }^{12}$. Literaturę przedmiotu stanowią opracowania z zakresu rozwijającej się współcześnie teologii gier wideo ${ }^{13}$.

W badaniu przyjęto metodologię teologii mediów i komunikacji. Obejmuje ona nie tylko analizę dokumentów kościelnych - tzw. podejście magisterialne - ale jest przede wszystkim badaniem współczesnych fenomenów kultury medialnej w kontekście religijnym, dostarczaniem spójnego i całościowego obrazu danego zjawiska

12 Jan Paweł II, Orędzie na 36. Światowy Dzień Środków Społecznego Przekazu. Internet: nowe forum głoszenia Ewangelii, Watykan 2002; Papieska Rada ds. Środków Społecznego Przekazu, Etyka w Internecie, Watykan 2002; Kościót a Internet, Watykan 2002; Benedykt XVI, Orędzie na 41. Światowy Dzień Środków Społecznego Przekazu. Dzieci i środki komunikowania: wyzwanie dla wychowania, Watykan 2007; Orędzie na 43. Światowy Dzień Środków Społecznego Przekazu. Nowe technologie, nowe relacje. Krzewić kulture poszanowania, dialogu i przyjaźni, Watykan 2009; Orędzie na 45. Światowy Dzień Środków Społecznego Przekazu. Prawda, przepowiadanie i autentyczność życia $w$ erze cyfrowej, Watykan 2011; Orędzie na 47. Światowy Dzień Środków Społecznego Przekazu. Portale społecznościowe: bramy prawdy $i$ wiary, nowe przestrzenie dla ewangelizacji, Watykan 2013; Franciszek, Orędzie na 53. Światowy Dzień Środków Społecznego Przekazu. „Wszyscy tworzymy jedno” (Ef 4,25). Od wirtualnych wspólnot społecznościowych do wspólnot ludzkich, Watykan 2019.

13 F.G. Bosman, The Incarnated Gamer: The Theophoric Quality of Games, Gaming, and Gamers, w: Boundaries of Self and Reality Online: Implications of Digitally Constructed Realities, red. J. Gackenbach, J. Bown, Cambridge 2017, s. 187-203; F.G. Bosman, A.L. H. M. Van Wieringen, I have faith in thee, lord: Criticism of religion and child abuse in the video game the binding of Isaac, ,Religions" 2018, t. 9, nr 4, s. 133; P. Popiołek, Prolegomena do teologii gier wideo. Ku teologicznej refleksji nad fenomenem gier cyfrowych, w: Dyskursy gier wideo, red. M. Kłosiński, K.M. Maj, Kraków 2019, s. 237-266; J. Wise, The call to endless adventure: The dynamic unending ascent into God and virtual worlds, „Dialog” 2019, t. 58, nr 4, s. 307-315. 
study of the theology of sport seems to be an undertaking far beyond the scope of this article, more inclined to monographic research. Therefore, the aim of the analysis is to determine the teachings of the Catholic Church on media and communication about e-Sports, as well as to indicate the problematic issues not yet addressed in the Magisterium concerning team games of video games in virtual reality.

\section{MATERIALS AND METHODS}

Our research is primarily rooted in the teachings of the Catholic Church on media and communication, focusing in particular on virtual reality, the Internet, and social media. ${ }^{12}$ The literature on the subject includes studies in the contemporary developing theology of video games. ${ }^{13}$

12 John Paul II, Message for the 36th World Communications Day. Internet: A New Forum for Proclaiming the Gospel, Vatican 2002; Pontifical Commission for Social Communications, Ethics in Internet, Vatican 2002; The Church and Internet, Vatican 2002; Benedict XVI, Message for the 41st World of Communications Day. Children and the Media: a Challenge for Education, Vatican 2007; Message for the 43rd World Communications Day. New technologies, New Relationships. Promoting a Culture of Respect, Dialogue and Friendship, Vatican 2009; Message for the 45th World Communications Day. Truth, Proclamation and Authenticity of Life in the Digital Age, Vatican 2011; Message for the 47th World Communications Day. Social Networks: portals of truth and faith; new spaces for evangelization, Vatican 2013; Francis, Message for the 53rd World Communications Day. "We are members one of another" (Eph 4,25). From social network communities to the human community, Vatican 2019.

13 F.G. Bosman, The Incarnated Gamer: The Theophoric Quality of Games, Gaming, and Gamers, w: Boundaries of Self and Reality Online: Implications of Digitally Constructed Realities, ed. J. Gackenbach, J. Bown, Cambridge 2017, pp. 187-203; F.G. Bosman, A.L. H.M. Van Wieringen, I have faith in thee, lord: Criticism of religion and child abuse in the video game the binding of Isaac, „Religions" 2018, vol. 9, no. 4, p. 133; P. Popiołek, Prolegomena do teologii gier wideo. Ku teologicznej refleksji nad fenomenem gier cyfrowych [Prolegomena to the theology of video games. Towards a theological reflection on the phenomenon of digital games] in Dyskursy gier wideo [Discourses of video games], ed. 
medialnego, a następnie podejmowaniem interpretacji teologicznych $^{14}$. Metodą pomocniczą jest jakościowa analiza i krytyka piśmiennictwa, ułatwiająca porządkowanie literatury naukowej oraz wyodrębnianie poszczególnych kategorii problemowych ${ }^{15}$.

\section{REZULTATY}

\section{E-sport w świetle dokumentów Kościoła katolickiego o mediach}

Pojęcie e-sportu nie występuje bezpośrednio we współczesnym nauczaniu Kościoła katolickiego o mediach i komunikacji. Możemy jednak wskazać na trzy istotne kategorie problemowe, dotyczące pośrednio sportu elektronicznego jako fenomenu medialno-komunikacyjnego w perspektywie teologicznej. Po pierwsze, jest to problematyka osoby i wspólnoty w świecie wirtualnym, pod drugie, zagadnienie ewangelizacji z uwzględnieniem współczesnych technologii cyfrowych, po trzecie, kwestia odpowiedzialności moralnej użytkowników rzeczywistości wirtualnej. W części dyskusyjnej artykułu podejmiemy próbę przedstawienia interpretacji teologiczno-medialnej e-sportu w oparciu o poniżej dokonaną analizę dokumentów Magisterium.

Po pierwsze, w nauczaniu Kościoła o mediach, zwłaszcza w kontekście rozwoju technologii cyfrowych, pojawia się pytanie o osobę i relacje w świecie wirtualnym. Papież Franciszek podkreśla, że nie można traktować pojęcia wirtualnej wspólnoty społecznościowej jako synonimu realnej bliskości. Wskazuje, że co prawda istnieje pewna „spójność i solidarność” takiej wspólnoty, jednak często ma charakter „skupisk osób, które rozpoznają się wokół interesów lub kwestii charakteryzujących się słabymi więzami”, zwłaszcza w serwisach

14 A. Adamski, G. Łęcicki, Teologia mediów i komunikacji - na styku nauk o mediach oraz nauk teologicznych, ,Studia Medioznawcze” 2016, t. 65, nr 2, s. 19.

15 S. Cisek, Metoda analizy i krytyki piśmiennictwa w nauce o informacji i bibliotekoznawstwie w XXI wieku, „Przegląd Biblioteczny” 2010, t. 78, nr 3, s. 273-284. 
The study adopts the methodology of media and communication theology. It includes not only the analysis of ecclesiastical documents , the so-called magisterial approach, but is mainly a study of contemporary phenomena of media culture in a religious context, providing a coherent and comprehensive picture of a given media phenomenon, and then undertaking theological interpretations. ${ }^{14}$ The auxiliary method is the qualitative analysis and criticism of the literature, which facilitates the ordering of scientific literature and the isolation of particular problem categories. ${ }^{15}$

\section{FINDINGS}

\section{e-Sports in the light of the documents of the Catholic Church on the media}

The concept of e-Sports does not appear directly in the contemporary teaching of the Catholic Church on media and communication. However, there are three important problem categories which indirectly concern e-Sports as a media and communication phenomenon in the theological perspective. Firstly, it is the problem of person and community in the virtual world; secondly, the issue of evangelization taking into account modern digital technologies; thirdly, the issue of moral responsibility of the users of virtual reality.

M. Klosiński, K.M. Maj, Kraków 2019, pp. 237-266; J. Wise, The call to endless adventure: The dynamic unending ascent into God and virtual worlds, „Dialog” 2019, vol. 58, no. 4, pp. 307-315.

14 A. Adamski, G. Lęcicki, Teologia mediów i komunikacji - na styku nauk o mediach oraz nauk teologicznych [Theology of media and communication - at the interface of media science and theological sciences], „Media Studies” 2016, vol. 65, no. 2, p. 19.

15 S. Cisek, Metoda analizy i krytyki piśmiennictwa $w$ nauce o informacji $i$ bibliotekoznawstwie $w$ XXI wieku [Methods of analysis and criticism of writing in information and library science in the 21st century, „Przegląd Biblioteczny” [Library Review] 2010, vol. 78, no. 3, pp. 273-284. 
społecznościowych, w których tożsamość „opiera się na przeciwieństwie wobec innego, nienależącego do grupy: określa się wychodząc od tego, co dzieli, a nie od tego, co łączy, eksponując podejrzliwość i dając upust wszelkiego rodzaju uprzedzeniom (etnicznym, seksualnym, religijnym i innym)". To ,podsyca niepohamowany indywidualizm w środowisku cyfrowym, doprowadzając czasami do podżegania spirali nienawiści. To, co powinno być oknem na świat, staje się zatem witryną, w której eksponuje się własny narcyzm"16. Analizując problem osoby i wspólnoty w świecie wirtualnym, możemy wskazać na szczegółowe, integralnie ujęte zagadnienia: autentyczności osoby w świecie wirtualnym oraz przyjaźni jako istotnej wartości w relacjach międzyludzkich, szczególnie obecne w nauczaniu papieża Benedykta XVI o mediach. Ojciec święty dostrzega kluczową rolę współczesnych środków komunikacji, zwłaszcza w życiu młodych ludzi, zauważa ich „kreatywność”, „entuzjazm”, ale i „obawy” związane $\mathrm{z}$ obecnością, „na publicznym forum cyfrowym, tworzonym przez tzw. sieci społecznościowe”. Podkreśla, że „obecność w tych przestrzeniach wirtualnych może być oznaką autentycznego poszukiwania spotkania osobistego z drugim, jeśli zwraca się uwagę na uniknięcie takich jej niebezpieczeństw, jak chronienie się w jakimś świecie paralelnym, lub nadmierna ekspozycja na świat wirtualny". Istotną znaczenie ma tu ,poszukiwanie dzielenia się”, przyjaźni, wyzwanie „bycia autentycznym i wiernym wobec siebie”, bez ulegania złudzeniu „sztucznego budowania swego «profilu» społecznościowego"17. Papież stawia istotne pytania w tym kontekście: „Kto jest moim «bliźnim» tym nowym świecie? Czy istnieje zagrożenie mniejszej obecności dla tych, których spotykamy w naszym zwykłym codziennym życiu? Czy istnieje ryzyko większego rozproszenia, ponieważ

${ }^{16}$ Franciszek, Orędzie na 53. Światowy Dzień Środków Społecznego Przekazu. "Wszyscy tworzymy jedno" (Ef 4,25). Od wirtualnych wspólnot społecznościowych do wspólnot ludzkich, Watykan 2019.

17 Benedykt XVI, Orędzie na 45. Światowy Dzień Środków Społecznego Przekazu. Prawda, przepowiadanie i autentyczność życia w erze cyfrowej, Watykan 2011. 
Finally, this paper will attempt to present a theological and media interpretation of e-Sports on the basis of the analysis of the documents of the Magisterium below.

First, in the Church's teaching on the media, especially in the context of the development of digital technologies, the question of the person and relationships in the virtual world arises. Pope Francis stresses that the concept of a virtual social community cannot be treated as synonymous with real intimacy. He points out that although there is a certain „,cohesion and solidarity" of such a community, it often comes in the form of ,groups of individuals who recognize one another through common interests or concerns characterized by weak bonds," especially in social networks where identity ,is too often based on opposition to the other, the person outside the group: we define ourselves starting with what divides us rather than with what unites us, giving rise to suspicion and to the venting of every kind of prejudice (ethnic, sexual, religious and other).” It „nourish unbridled individualism which sometimes ends up fomenting spirals of hatred. In this way, what ought to be a window on the world becomes a showcase for exhibiting personal narcissism." When analyzing the problem of person and community in the virtual world, one can point to specific, integral issues such as: the authenticity of the person in the virtual world and friendship as an essential value in human relationships, especially present in the teaching of Pope Benedict XVI on the media. The Holy Father recognizes the crucial role of modern means of communication, especially in the lives of young people, and he notes their „creativity," their „enthusiasm," but also their ,anxiety" about being present ,,in the public digital forum, created by the so-called social networks." He stresses that ,(e)ntering cyberspace can be a sign of an authentic search for personal encounters with others, provided that attention is paid to avoiding dangers such as enclosing oneself in a sort of parallel existence, or excessive exposure to the virtual world." What is crucial here is the „search for sharing", for friendship, the challenge to ,be authentic and faithful” to one another, "and not give in to the illusion of constructing an artificial 
nasza uwaga jest podzielona i pochłonięta «innym» światem niż ten, w którym żyjemy? Czy mamy czas, aby krytycznie myśleć o naszych wyborach i umacniać relacje międzyludzkie, aby były naprawdę głębokie i trwałe?”. Zwraca uwagę, że ,kontakt wirtualny nie może i nie powinien zastępować bezpośredniego kontaktu z ludźmi na wszystkich poziomach naszego życia""18. Szczególne znaczenie tutaj ma wartość przyjaźni międzyludzkiej. Należy ona do „największych bogactw, jakimi może dysponować człowiek. Z tego względu trzeba uważać, by nie banalizować koncepcji i doświadczenia przyjaźni”. „Przyjaźń on-line” nie może być realizowana „kosztem dyspozycyjności dla rodziny, dla bliskich i tych, których spotykamy w codziennej rzeczywistości - w miejscu pracy, w szkole, w czasie wolnym". Inaczej staje się „obsesyjną”, prowadzi do „wyizolowania osoby i zerwania realnej interakcji społecznej”, zaburza również „modele odpoczynku, ciszy i niezbędnej do ludzkiego rozwoju refleksji”. Przyjaźń nie może być również „celem samym w sobie”, lecz wzajemną pomocą i zachętą do rozwijania ,darów i talentów oraz ofiarowywania ich w służbie wspólnoty ludzkiej"'19.

Drugą istotną kategorię współczesnego nauczania Kościoła o mediach w kontekście rzeczywistości wirtualnej stanowi zagadnienie ewangelizacji z uwzględnieniem współczesnych technologii cyfrowych. Przede wszystkim podkreślono realizm Ewangelii. Benedykt XVI dostrzega, że ,świadczenia Ewangelii w erze cyfrowej” stanowi istotne „wyzwanie dla współczesnej mentalności internetowej”. Jednocześnie przekonuje, że Ewangelia ,chociaż głoszona w przestrzeni sieci wirtualnej, wymaga zawsze wcielenia w świat rzeczywisty oraz odniesienia do twarzy konkretnych braci i sióstr, z którymi dzielimy nasze życie powszednie". Dlatego w przekazywaniu wiary kluczowe

18 Tamże; zob. też. P. Drzewiecki, Kto jest moim bliźnim w wirtualnym świecie? Teologia społeczności sieciowych w orędziach Benedykta XVI na Światowe Dni Środków Społecznego Przekazu, „Łódzkie Studia Teologiczne” 2011, t. 20, nr 1, s. 55-66.

19 Benedykt XVI, Orędzie na 43. Światowy Dzień Środków Społecznego Przekazu. Nowe technologie, nowe relacje. Krzewić kulture poszanowania, dialogu i przyjaźni, Watykan 2009. 
public profile for oneself." ${ }^{\prime 16}$ The Pope poses important questions in this context: „Who is my ,neighbour' in this new world? Does the danger exist that we may be less present to those whom we encounter in our everyday life? Is there is a risk of being more distracted because our attention is fragmented and absorbed in a world "other" than the one in which we live? Do we have time to reflect critically on our choices and to foster human relationships which are truly deep and lasting?" He points out that , virtual contact cannot and must not take the place of direct human contact with people at every level of our lives." 17 The value of interpersonal friendship is especially important here. It is „one of the greatest goods any human person can experience. We should be careful, therefore, never to trivialize the concept or the experience of friendship." „On-line friendship" cannot ,be at the cost of our availability to engage with our families, our neighbours and those we meet in the daily reality of our places of work, education and recreation.” Otherwise, it becomes „obsessive," leads to "isolate[ing] individuals from real social interaction while also disrupting the patterns of rest, silence and reflection that are necessary for healthy human development." Nor can friendship be „an end in itself," but a mutual help and encouragement to develop ,gifts and talents and in putting them at the service of the human community. " ${ }^{18}$

The second major category of the Church's contemporary teaching on media in the context of virtual reality is the issue of evangelization with contemporary digital technologies. First of all, the realism of the Gospel is emphasized. Benedict XVI recognizes that ,, $(\mathrm{t})$ he task of witnessing to the Gospel in the digital era" represents a significant

${ }_{16}$ Benedict XVI, Message for the 45th World Communications Day. Truth, Proclamation and Authenticity of Life in the Digital Age, Vatican 2011.

17 Ibid; see also. P. Drzewiecki, Who is my neighbour in the virtual world? Theology of network communities in the messages of Benedict XVI for World Communications Day, „, ódzkie Studia Teologiczne” 2011, vol. 20, no. 1, pp. 55-66.

18 Benedict XVI, Message for the 43rd World Communications Day. New technologies, New Relationships. Promoting a Culture of Respect, Dialogue and Friendship, Vatican 2009. 
znaczenie mają nadal „bezpośrednie relacje międzyludzkie!”20. Jan Paweł II podejmując zagadnienie ewangelizacji cyfrowej apelował o ,pomoc tym wszystkim, którzy po raz pierwszy stykają się z chrześcijaństwem za pośrednictwem Internetu, aby mogli przejść z wirtualnego świata cyberprzestrzeni do rzeczywistego świata wspólnoty chrześcijańskiej" 21 . Mając na uwadze to przekonanie o realizmie ewangelicznym, dostrzeżono pewne możliwości cyfrowego głoszenia Dobrej Nowiny. Zawsze jednak ma ono prowadzić do wspólnoty rzeczywistej, przede wszystkim ze względu na sakramentalny wymiar Kościoła. Rzeczywistość wirtualna bowiem „nie jest zamiennikiem Realnej Obecności Chrystusa w Eucharystii”, nie ma w niej „,rzeczywistości sakramentów i współudziału w kulcie sprawowanym w żywej wspólnocie”, a „doświadczenia religijne, możliwe dzięki łasce Boga nie są wystarczające w oderwaniu od współdziałania z innymi wiernymi w świecie rzeczywistym". Istotne, aby ,przeprowadzić ludzi z cyberprzestrzeni do prawdziwej wspólnoty", sama rzeczywistość wirtualna może być jednak wykorzystana „do podtrzymywania ich i umacniania w zaangażowaniu chrześcijańskim”22. Ułatwia bowiem „dostęp do ważnych zasobów religijnych i duchowych - wspaniałych bibliotek i muzeów oraz miejsc kultu, dokumentów i nauczania Magisterium, pism Ojców i Doktorów Kościoła oraz duchowej mądrości wieków”. Należy uwzględnić te możliwości „W wielu rodzajach działalności i programach kościelnych - ewangelizacji, w tym zarówno reewangelizacji, nowej ewangelizacji, jak i tradycyjnej misyjnej posłudze ad gentes, katechezie i innych rodzajach edukacji, wiadomościach i informacjach, apologetyce, zarządzaniu i administracji oraz pewnych formach duszpasterskiego poradnictwa i kierownictwa duchowego". Wreszcie dostarcza ona

20 Benedykt XVI, dz. cyt., Watykan 2011.

21 Jan Paweł II, Orędzie na 36. Światowy Dzień Środków Społecznego Przekazu. Internet: nowe forum głoszenia Ewangelii, Watykan 2002.

22 Papieska Rada ds. Środków Społecznego Przekazu, Kościół a Internet, Watykan 2002, nr 9; zob też. P. Drzewiecki, Bezcielesność cyberprzestrzeni a sakramentalny wymiar Kościoła, „Biuletyn Edukacji Medialnej” 2008, nr 1, s. 108-115. 
„challenge [of] some of the ways of thinking typical of the web." At the same time, he argues that the Gospel, ,(e)ven when it is proclaimed in the virtual space of the web, the Gospel demands to be incarnated in the real world and linked to the real faces of our brothers and sisters, those with whom we share our daily lives.” Therefore, ,(d) irect human relations always remain fundamental for the transmission of the faith!"'19 In addressing the issue of digital evangelization, John Paul II appealed we should think of ,ways of helping those who first make contact through the Internet to move from the virtual world of cyberspace to the real world of Christian community." 20 With this conviction of evangelical realism in mind, certain possibilities for the digital proclamation of the Good News were recognized. However, it must always lead to a real community, primarily because of the sacramental dimension of the Church. "Virtual reality is no substitute for the Real Presence of Christ in the Eucharist," there is no ,sacramental reality of the other sacraments, and shared worship in a flesh-and-blood human community. There are no sacraments on the Internet; and even the religious experiences possible there by the grace of God are insufficient apart from real-world interaction with other persons of faith.” It is essential to „lead people from cyberspace to true community," but virtual reality itself can be used „to sustain and enrich them in their Christian commitment." ${ }^{21}$ For ,(i)t offers people direct and immediate access to important religious and spiritual resources-great libraries and museums and places of worship, the teaching documents of the Magisterium, the writings of the Fathers and Doctors of the Church and the religious wisdom of the ages.” These opportunities should be considered ,relevant to many activities and programs of the Church - evangelization,

19 Benedict XVI, cit., Vatican 2011.

20 John Paul II, Message for the 36th World Communications Day. Internet: A New Forum for Proclaiming the Gospel, Vatican 2002.

21 Pontifical Council for Social Communications, The Church and Internet, Vatican 2002, no. 9; see also. P. Drzewiecki, Bezcielesność cyberprzestrzeni a sakramentalny wymiar Kościoła [The incorporeality of cyberspace and the sacramental dimension of the Church], „Biuletyn Edukacji Medialnej” 2008, no 1, p. 108-115. 
„Środka komunikacji w stosunku do szczególnych grup - młodzieży i młodych osób dorosłych, osób starszych i zamkniętych w domach, żyjących na odległych terenach, członków innych grup religijnych z którymi kontakt innymi sposobami jest utrudniony"23.

Trzecia kategoria problemowa obecna w nauczaniu Kościoła o mediach dotyczy odpowiedzialności moralnej użytkowników rzeczywistości wirtualnej. Przede wszystkim powstaje problem nadmiaru informacji internetowych oraz braku możliwości ich należytej weryfikacji. Pojawia się również kwestia otwartości na innych użytkowników i ich przekonania światopoglądowe. Istnieje bowiem ryzyko budowania „zapór elektronicznych” w miejsce tworzenia „pluralistycznego świata, w którym ludzie powinni wzrastać we wzajemnym zrozumieniu”. Stąd obawy i krytyczne pytania: „czy w przyszłości społeczeństwo będzie zbiorem wielu społeczności złożonych z pojedynczych ludzi?”, „co w takim świecie stanie się z solidarnością i miłością?" ${ }^{24}$. Rzeczywistość wirtualna daje jednak „szansę przezwyciężania odległości i izolacji”, umożliwia „kontakt z podobnie myślącymi ludźmi dobrej woli, którzy łączą się w wirtualnych społecznościach wiary, by nawzajem zachęcać się i wspierać" 25 . Kwestia moralnej odpowiedzialności użytkowników rzeczywistości wirtualnej obejmuje również zagadnienie zawartości przekazów, w tym współczesnych gier komputerowych. O ile ich funkcja rozrywkowa nie budzi wątpliwości, o tyle jednak powstaje problem nadużywanej współcześnie narracji antywartości. Zauważamy bowiem tendencję do produkcji, które „w imię rozrywki sławią przemoc, odzwierciedlają postawy antyspołeczne czy wulgaryzują ludzką płciowość, stanowi perwersję". Ma to szczególne znaczenie

23 Tamże, nr 5.

24 Papieska Rada ds. Środków Społecznego Przekazu, Etyka w Internecie, Watykan 2002, nr 30.

25 Papieska Rada ds. Środków Społecznego Przekazu, Kościół a Internet, dz. cyt., nr 5. 
including both re-evangelization and new evangelization and the traditional missionary work ad gentes, catechesis and other kinds of education, news and information, apologetics, governance and administration, and some forms of pastoral counseling and spiritual direction.” Finally, it provides ,a means for communicating with particular groups - young people and young adults, the elderly and home-bound, persons living in remote areas, the members of other religious bodies - who otherwise may be difficult to reach." ${ }^{22}$

The third category of problems present in the teaching of the Church about the media concerns the moral responsibility of virtual reality users. First of all, there is the problem of the excess of information on the Internet and a lack of the possibility of its proper verification. There is also the question of openness to other users and their worldview beliefs. There is a risk of building ,electronic barriers" instead of creating ,a pluralistic world where people need to grow in mutual understanding." Hence the concerns and critical questions: "Will the audience of the future be a multitude of audiences of one?...What would become of solidarity — what would become of love-in a world like that?"23 Virtual reality, however, offers „capacity to overcome distance and isolation,” enables ,,contact with like-minded persons of good will who join in virtual communities of faith to encourage and support one another." 24 The issue of moral responsibility of users of virtual reality also includes the issue of the content of media, including popular computer games. While their entertainment function is undeniable, there arises the problem of the overused contemporary narrative of anti-value. We notice a tendency for productions that ,in the name of entertainment exalt violence and portray anti-social behaviour or the trivialization of human sexuality is a perversion." This is particularly important

22 Ibid, no. 5.

23 Pontifical Council for Social Communications, Ethics and Internet, Vatican 2002, no. 30.

24 Pontifical Council for Social Communications, The Church and Internet, op. cit., no. 5. 
dla wychowania dzieci i dorastającej młodzieży, coraz częściej będącej „ofiarami przemocy, wyzysku i nadużyć” w rzeczywistości wirtualnej $^{26}$.

\section{E-sport w perspektywie współczesnej teologii gier wideo}

Trudno wskazać na funkcjonowanie terminu teologia e-sportu w literaturze przedmiotu, jednak w trakcie kwerendy dostrzeżono publikacje dotyczące teologicznej interpretacji gier wideo, co ma istotny związek z powziętym tu tematem. Możemy wyodrębnić dwie znaczące kategorie problemowe w tym zakresie: wysiłki zmierzające do systematyzacji teologii gier wideo oraz podejmowanie teologicznej krytyki ich zawartości.

Po pierwsze, należy wymienić współczesne badania mające na celu całościowe i systematyczne ujęcie teologii gier wideo. Podkreśla się, że teologia jako dyscyplina akademicka jest wyraźnie w tyle za innymi naukami humanistycznymi w tym zakresie. Tymczasem gry wideo stały się jednym z najważniejszych artefaktów kulturowych, w tym mediatorem wartości religijnych, co czyni z nich przedmiot teologii kultury. Przede wszystkim istotny wydaje się problem zła przedstawiony $w$ grach wideo, co lokuje zagadnienie również w obszarze współczesnej teodycei i teologii moralnej. Nie mniej zasadnicza jest problematyka śmierci, szczególnie przy omawianiu znaczenia pojęcia „końca gry” czy też kwestii „,wielo-życiowości” postaci ukazanych w grach, co skłania do badań na gruncie tanatologii teologicznej czy też eschatologii. Wreszcie możemy wskazać na problem świata przedstawionego w grach wideo, na ontyczny status prezentowanych postaci - niekiedy przybierających charakter „półbogów” czy herosów, tzw. problem teomorfizmu - co stanowi kluczowe wyzwanie dla teologii stworzenia, antropologii teologicznej

26 Benedykt XVI, Orędzie na 41. Światowy Dzień Środków Społecznego Przekazu. Dzieci i środki komunikowania: wyzwanie dla wychowania, Watykan 2007. 
when upbringing children and adolescents, who increasingly ,suffer violence, exploitation and abuse" in virtual reality. ${ }^{25}$

\section{E-sports in the perspective of theology of contemporary video games}

While it is difficult to pinpoint how the term e-Sports theology is used in the literature, the search yielded a number of publications on the theological interpretation of videogames that are relevant to the subject under consideration here. Two major categories of problems can be identified in this regard, i.e. efforts to systematize the theology of video games and undertaking a theological critique of their content.

First and foremost, it is important to mention contemporary research aiming at a holistic and systematic account of the theology of video games. It is pointed out that theology as an academic discipline is clearly lagging behind other humanities in this regard. Meanwhile, video games have become one of the most important cultural artifacts, including a mediator of religious values, which makes them a subject of cultural theology. In particular, the problem of evil portrayed in video games seems to be vital and this places the issue within the realm of contemporary theodicy and moral theology. The problem of death is also crucial, especially when discussing the meaning of the notion of, end of the game" or the issue of the ,multi-life" of characters depicted in games, which encourages research in the field of theological thanatology or eschatology. Last but not least, we can point to the problem of the world of video games, the ontic status of the characters presented to the gamer sometimes taking on the character of ,demigods" or heroes, the socalled ,problem of theomorphism”, which is a key challenge for

25 Benedict XVI, Message for the 41st World Communications Day. Children and the Media: A Challenge for Education, Vatican 2007. 
i chrystologii ${ }^{27}$. W badaniach poszukuje się szeroko pojętych związków między religią a grami wideo, np. między ludyczną i narracyjną funkcją religii a dramaturgią postaci w grach. Powstają pytania o uniwersum gry wideo, o to komu przypisać rolę absolutu czy demiurga świata w nich przedstawionego. Istotnym zagadnieniem jest kwestia awataryzacji w grach wideo, możliwość imersji i wcielania się graczy $\mathrm{w}$ określone postaci czy też problem uczestnictwa w wirtualnym świecie stanowiący pewien rodzaj kenozy, wycofania się z własnej natury, tutaj przez rezygnację z bezpośrednich kontaktów międzyludzkich na rzecz bytowania $\mathrm{w}$ formie określonej przez twórców gry wideo $^{28}$. Podejmowane są również badania nad epektazą w grach komputerowych. Pojęcie to wskazuje na chrześcijańskie dążenie do doskonałości (Flp 3, 13), mogące obejmować również świat wirtualny, co więcej podkreślono, że uczestnictwo w grze wideo może stanowić pewną formę doskonalenia w wierze, w zmierzaniu do ostatecznego celu człowieka ${ }^{29}$.

Po drugie, możemy również mówić o teologicznej krytyce zawartości gier wideo, można powiedzieć, że stanowiącej pewną metodę chrześcijańskiej ich interpretacji. Na początku dokonuje się opisu danej gry, jej świata przedstawionego, postaci oraz dramaturgii. Następnie podejmuje się analizy zgodności religijnej, np. z nauczaniem Kościoła katolickiego. Przykładem tak prowadzonego badania jest teologiczna analiza i krytyka The Binding of Isaac, gry stanowiącej uwspółcześnienie biblijnej opowieści o Izaaku ( $\mathrm{Rdz} 22$, 1-19). Młody chłopiec jest zagrożony przez matkę z zaburzeniami psychicznymi, która słyszy „głosy z góry”, które nakazują jej złożyć w ofierze swoje jedyne dziecko. W narracji tej gry wideo można znaleźć wiele krytycznych odniesień do chrześcijaństwa, do siedmiu

27 F.G. Bosman, Gaming and the Divine: A New Systematic Theology of Video Games, London 2019.

28 P. Popiołek, Prolegomena do teologii gier wideo. Ku teologicznej refleksji nad fenomenem gier cyfrowych, w: Dyskursy gier wideo, red. M. Kłosiński, K.M. Maj, Kraków 2019, s. 237-266.

29 J. Wise, The call to endless adventure: The dynamic unending ascent into God and virtual worlds, „Dialog” 2019, t. 58, nr 4, s. 307-315. 
the theology of creation, theological anthropology and Christology. ${ }^{26}$ The study looks broadly at the relationship between religion and video games, such as between the ludic and narrative function of religion and the dramaturgy of characters in games. Questions arise about the universe of video games, about whom to assign the role of absolute or demiurge of the world depicted in them. An important issue is the avatarization in video games, the possibility of imersion and the impersonation of players in specific characters, or the problem of participation in the virtual world, which is a kind of kenosis, a withdrawal from one's own nature, namely by abandoning direct human contact in favor of existence in a form defined by the creators of the video game. ${ }^{27}$ Research on epektasis in computer games is also undertaken. This notion points to the Christian pursuit of perfection (Phil 3:13), which can also include the virtual world; moreover, it has been emphasized that participation in a video game can represent a form of perfection in faith, in moving towards the ultimate goal of $\operatorname{man}^{28}$.

Secondly, the theological critique of video game content can also be said to provide a method for Christian interpretation of video games. It begins with a description of the game, its world, characters and drama, followed by an analysis of its religious compatibility, e.g. with the teachings of the Catholic Church. An example of such a study is a theological analysis and critique of The Binding of Isaac, a game that modernizes the biblical story of Isaac (Genesis 22:1-19). A young boy is threatened by a mentally disturbed mother who hears ,,voices from above" that command her to sacrifice her only

26 F.G. Bosman, Gaming and the Divine: A New Systematic Theology of Video Games, London 2019.

27 P. Popiołek, Prolegomena do teologii gier wideo. Ku teologicznej refleksji nad fenomenem gier cyfrowych [Prolegomena to the theology of video games. Towards theological reflection on the phenomenon of digital games], in: Dyskursy gier wideo [Discourses of Video Games], ed. M. Klosiński, K.M. Maj, Kraków 2019, pp. 237-266.

28 J. Wise, The call to endless adventure: The dynamic unending ascent into God and virtual worlds, ,Dialog” 2019, vol. 58, no. 4, pp. 307-315. 
grzechów głównych, różańca, Pisma Świętego, krucyfiksu czy biblijnych postaci, tj. Marii Magdaleny czy Judasza Iskarioty. Inspiracja twórcy The Binding of Isaac pochodziła z jego własnych doświadczeń $\mathrm{z}$ rodziną, złożoną zarówno z katolików, jak i wyznawców innych denominacji chrześcijańskich. Gra stanowi jednak zbyt sugestywne powiązanie psychicznego i fizycznego znęcania się z wiarą religijną, co istotnie domaga się krytyki teologicznej ${ }^{30}$. W badaniach tego nurtu poszukuje się również tzw. jakości teoforycznej i chrystoforycznej gier wideo. Przyjmujący postać awatara gracz może być bowiem zaproszony przez twórcę świata przedstawionego w grze do swoistej „rekonstrukcji boskich aktów stworzenia, odkupienia i spełnienia”, czego przykładem są m.in. produkcje Godus, Fallout 3, Child of Light i trylogia Mass Effect. Analiza i krytyka teologiczna gier wideo w tym podejściu zmierza do szukania związków między narracją i ontologią wirtualnego świata danej produkcji a zasadniczymi elementami zbawczego przesłania chrześcijańskiego ${ }^{31}$.

\section{DYSKUSJA}

Powyższa analiza dokumentów Kościoła katolickiego o mediach na temat rzeczywistości wirtualnej oraz współczesnych opracowań z zakresu teologii gier wideo, pozwala na dokonanie wstępnej interpretacji e-sportu jako fenomenu komunikacyjnego w perspektywie teologicznej. Próba taka nie została jeszcze wystarczająco podjęta ani przez Magisterium, ani w badaniach teologicznych. Interpretując zagadnienie, wskażemy na trzy zasadnicze wnioski: na możliwość bezpośredniego i wspólnotowego uczestnictwa w rozgrywce e-sportowej,

30 F.G. Bosman, A.L. H. M. Van Wieringen, I have faith in thee, lord: Criticism of religion and child abuse in the video game the binding of Isaac, ,Religions” 2018, t. 9, nr 4, s. 133.

31 F.G. Bosman, The Incarnated Gamer: The Theophoric Quality of Games, Gaming, and Gamers, w: Boundaries of Self and Reality Online: Implications of Digitally Constructed Realities, red. J. Gackenbach, J. Bown, Cambridge 2017, s. 187-203. 
child. The narrative of this video game features many critical references to Christianity, the seven deadly sins, the rosary, scripture, the crucifix, or biblical characters, i.e. Mary Magdalene and Judas Iscariot. The inspiration of the creator of The Binding of Isaac came from his own experiences with his family, consisting of both Catholics and followers of other Christian denominations. However, the game makes an overly suggestive connection between mental and physical abuse and religious faith, which indeed calls for a theological critique. ${ }^{29}$ The research of this trend also looks for the so-called theophoric and Christophoric quality of video games. The player may be invited by the creator of the world shown in the game to ,reconstruct the divine acts of creation, redemption and fulfillment," as exemplified by Godus, Fallout 3, Child of Light and the Mass Effect trilogy. The theological analysis and criticism of video games in this approach seeks to find connections between the narrative and ontology of the virtual world of a given production and the essential elements of the salvific message of Christianity. ${ }^{30}$

\section{DISCUSSION}

The above analysis of the Catholic Church's media documents on virtual reality and contemporary studies on the theology of video games allows for a preliminary interpretation of e-sports as a communication phenomenon in a theological perspective. Such an attempt has neither yet been sufficiently made by the Magisterium nor in theological research. The interpretation of the issue leads to three basic conclusions: the possibility of direct and communal participation in e-Sports gameplay, the question of religious and moral

29 F.G. Bosman, A.L. H.M. Van Wieringen, I have faith in thee, lord: Criticism of religion and child abuse in the video game the binding of Isaac, "Religions" 2018, vol. 9, no. 4, p. 133.

30 F.G. Bosman, The Incarnated Gamer: The Theophoric Quality of Games, Gaming, and Gamers, w: Boundaries of Self and Reality Online: Implications of Digitally Constructed Realities, ed. J. Gackenbach, J. Bown, Cambridge 2017, pp. 187-203. 
na kwestię religijnej i moralnej oceny zawartości gier e-sportowych oraz na zadania teologiczno-duszpasterskie w tym zakresie.

Po pierwsze, należy wskazać na istotną różnicę między e-sportem uprawianym zespołowo a indywidualnym uczestnictwem $\mathrm{w}$ grach komputerowych. Co do drugiej formy istnieje ryzyko zbyt dużej imersji - zanurzenia się - w rzeczywistość danej rozgrywki wirtualnej. Można mieć obawy natury psychologicznej, społecznej i pedagogicznej o charakter takiego uczestnictwa. Gracz zamienia się w awatara, pozostaje sam ze sobą podczas przebiegu rywalizacji, kontaktuje się jedynie z komputerem, z zaplanowanym przez twórcę gry światem o określonej narracji i aksjologii. Jest de facto sam przed ekranem. Nieco odmienna sytuacja antropologiczno-kulturowa występuje w przypadku rozgrywki zespołowej. Gracze często kontaktują się ze sobą za pomocą zestawu mikrofonowo-słuchawkowego. Ich aktywność wymaga współpracy ze sobą, wymiany zdań w trakcie rozgrywki, ustalania podziału ról, taktyki i strategii. Choć nadal mamy do czynienia z zanurzeniem się w świat wirtualny, to jednak w tym wypadku imersja zostaje złagodzona dodatkowymi formami kontaktu między graczami, nadal pośredniego medialnie, ale jednak już w mniejszym stopniu stanowiącego przejaw alienacji ze świata realnego. Co więcej, w przypadku organizowanych współcześnie turniejów e-sportowych - tego typu rozgrywki możemy śledzić m.in. za pośrednictwem kanału telewizyjnego Polsat Games czy też podczas wspomnianego już Intel Extreme Masters - kontakty te przybieraja również formę bezpośrednią. Zawodnicy i widownia znajdują się w hali sportowej, gdzie mają możliwość oglądania swoich faworytów na telebimach. Tego typu forma e-sportowa może wówczas sprzyjać budowaniu wspólnoty między audytorium a graczami, czy też graczami między sobą. Stanowi istotne uzupełnienie świata wirtualnego o realną formę kontaktu. Równie zasadniczą jest kwestia autentyczności graczy, na ile postrzegają oni siebie jako awatary, w których role wcielają się w rozgrywce, a na ile siebie samego jako realnie istniejących zawodników, mających swój świat zainteresowań i relacji przyjacielskich poza e-sportową formą rywalizacji. 
evaluation of the content of e-Sports games, and the theological and pastoral tasks in this regard.

First, it is important to identify an important difference between team-based e-Sports and individual participation in computer games. As far as the latter is concerned, there is a risk of too deep immersion in the reality of a given virtual game. The player turns into an avatar, remains all alone throughout the competition, interacts only with the computer, with the world designed by the game developer with a specific narrative and axiology. $\mathrm{S} /$ he is de facto on his/her own in front of the screen. A slightly different anthropological and cultural situation occurs in the case of team play. Players often interact with each other through a microphone and a headset. Their activity requires them to collaborate with each other, exchange ideas during the game, determine the division of roles, tactics, and strategies. Although there is still an immersion in the virtual world, in this case the immersion is mitigated by additional forms of contact between the players, indirect in media terms, yet less a manifestation of alienation from the real world. What is more, in case of today's e-Sports tournaments, which can be watched on Polsat Games TV channel or during Intel Extreme Masters mentioned above, the contact is also direct. The players and the audience are in the sports hall, where they can watch their favorites on the screens. This type of e-Sports form can then foster a sense of community between the audience and the players, or the players with one another. It provides an important complement to the virtual world with a real form of contact. Another equally fundamental issue is the question of the authenticity of the players, to what extent they perceive themselves as avatars whose roles they play in the game, and to what extent they perceive themselves as real players who have their own world of interests and friendly relations outside the e-Sports form of competition.

Second, an important question arises about the religious character of e-Sports, taking into account the aspect of moral responsibility for the use of virtual entertainment. It is difficult for a Christian to accept uncritically the universe of some computer games, which directly undermine the main truths of faith. Moreover, in such situations s/he 
Po drugie, pojawia się istotne pytanie o religijny charakter e-sportu, z uwzględnieniem aspektu odpowiedzialności moralnej za korzystanie z rozrywki wirtualnej. Chrześcijaninowi trudno przyjąć bezkrytycznie uniwersum niektórych gier komputerowych, w których wprost podważa się główne prawdy wiary. Co więcej w takich sytuacjach wymaga się od niego stanięcia w postawie apologetycznej. Ale istnieje też bardziej ukryta kwestia moralna, zgody na przedstawianie w grach komputerowych scen nadmiernej przemocy fizycznej i psychicznej, w tym seksualnej. Często nie wynika ona z potrzeb przedstawienia prawideł walki ekranowej, ale raczej stanowi wątpliwie etyczną formę uatrakcyjnienia świata gry. Można wskazać tutaj na drogę selektywnego odbioru, krytycznej interpretacji i chrześcijańskiego rozeznawania duchowego. Wierzący istotnie powinien poszukiwać epektazy w grach komputerowych, mieć na względzie to, jakie uniwersum ontyczno-moralne przedstawia dana gra, starać się doskonalić w umiejętnościach ekranowych, ale też etycznych.

Po trzecie, należy wskazać na zadania teologiczno-duszpasterskie w zakresie e-sportu. Brakuje opracowań z zakresu teologicznej interpretacji konkretnych produkcji wirtualnych, poszukiwania w nich wspomnianej jakości teoforycznej. Tymczasem jest to coraz częściej dominujący świat przekazów dzieci i młodzieży, co oznacza że należy uwzględnić problematykę gier wideo w szeroko rozumianych działaniach pedagogicznych, w tym na szkolnych lekcjach religii czy też w katechezie. Gry wideo powinny stawać się również nowym przedmiotem duszpasterstwa np. poprzez inicjowanie parafialnych klubów e-sportowych. Dla nauczyciela religii, katechety czy duszpasterza daje to możliwość nie tylko atrakcyjnej formy kontaktu z młodymi ludźmi, lecz także ich formacji chrześcijańskiej. Dostarcza również nowej perspektywy rozwoju tak często postulowanej współcześnie edukacji medialnej, czyli kształcenia kompetencji medialnych i wychowania do odpowiedzialnego korzystania z mediów. 
is required to stand in an apologetic stance. But there is also a more implicit moral issue of consent to the depiction in computer games of scenes of excessive physical and psychological violence, including sexual violence. It often does not stem from the need to depict the laws of screen combat, but rather constitutes a questionably ethical form of making the game world more attractive. One can indicate here the way of selective reception, critical interpretation and Christian spiritual discernment. Indeed, the believer should look for the epektasis in computer games, take into account what kind of ontic-moral universe a given game presents, and try to improve his/her screen skills as well as ethical ones.

And third, it is essential to point out the theological and pastoral tasks in the field of e-Sports. There is a lack of studies on the theological interpretation of specific virtual productions and the search for the theophoric quality mentioned above. However, video games are increasingly dominating the world of communication for children and adolescents, which means that video games should be taken into account in all pedagogical activities, including religious instruction and catechesis. Furthermore, video games should become a new pastoral concern, for example by initiating parish e-Sports clubs. For a religion teacher, catechist or pastor, this provides an opportunity not only for an attractive form of contact with young people, but also for their Christian formation. It also opens up a new perspective for the development of media education, so often postulated today, i.e. training in media competence and education for responsible use of the media. 


\begin{abstract}
Abstrakt
E-sport stał zjawiskiem kulturowym, społecznym i gospodarczym. Interesującym przedmiotem badań jest osoba i wspólnota graczy wirtualnych, a skoro zatem podejmuje się analiz antropologicznych, pojawiają się również pytania natury teologicznej. E-sport jest również przedmiotem współczesnych nauk o komunikacji społecznej i mediach, w tym teologii komunikacji i mediów. W artykule podjęto próbę ustalenia nauki Kościoła katolickiego o mediach i komunikacji na temat e-sportu, jak również interpretacji teologicznej nie podjętych jeszcze w Magisterium zagadnień dotyczących zespołowych rozgrywek gier wideo w rzeczywistości wirtualnej. Zastosowano metodę teologii mediów i komunikacji oraz metodę jakościowej analizy i krytyki piśmiennictwa.
\end{abstract}

Słowa kluczowe: e-sport, gry wideo, rzeczywistość wirtualna, teologia mediów i komunikacji

\title{
Bibliografia
}

Adamski A., Łęcicki G., Teologia mediów i komunikacji-na styku nauk o mediach oraz nauk teologicznych, „Studia Medioznawcze” 2016, t. 65, nr 2, s. 11-20.

Benedykt XVI, Orędzie na 41. Światowy Dzień Środków Społecznego Przekazu. Dzieci i środki komunikowania: wyzwanie dla wychowania, Watykan 2007.

Benedykt XVI, Orędzie na 43. Światowy Dzień Środków Społecznego Przekazu. Nowe technologie, nowe relacje. Krzewić kulture poszanowania, dialogu i przyjaźni, Watykan 2009.

Benedykt XVI, Orędzie na 45. Światowy Dzień Środków Społecznego Przekazu. Prawda, przepowiadanie i autentyczność życia w erze cyfrowej, Watykan 2011. Benedykt XVI, Orędzie na 47. Światowy Dzień Środków Społecznego Przekazu. Portale społecznościowe: bramy prawdy i wiary, nowe przestrzenie dla ewangelizacji, Watykan 2013.

Bosman F.G., The Incarnated Gamer: The Theophoric Quality of Games, Gaming, and Gamers, w: Boundaries of Self and Reality Online: Implications of Digitally Constructed Realities, red. J. Gackenbach, J. Bown, Cambridge 2017, s. 187-203.

Bosman F.G., Gaming and the Divine: A New Systematic Theology of Video Games, London 2019.

Bosman F.G., Van Wieringen A.L. H. M., I have faith in thee, lord: Criticism of religion and child abuse in the video game the binding of Isaac, „Religions” 2018, t. 9, nr 4, s. 133. 


\begin{abstract}
Esports has become a cultural, social and economic phenomenon. An interesting subject of research is the person and community of virtual players, and - since anthropological analyzes are undertaken - we can ask some theological questions. Esports is also a subject of modern communication and media studies, including communication and media theology. The article is an attempt to establish the teachings of the Catholic Church on the media and communication on esports, as well as the theological interpretation of issues - not yet discussed in the Magisterium Ecclesiae - regarding team games in virtual reality. We use the method of media and communication theology as well as the method of qualitative analysis and criticism of the literature.
\end{abstract}

Keywords: esports, media and communication theology, video games, virtual reality

\title{
Bibliography
}

A. Adamski, G. Łęcicki, Teologia mediów i komunikacji - na styku nauk o mediach oraz nauk teologicznych [Theology of media and communication - at the interface of media science and theological sciences], „Media Studies”2016, vol. 65 , no. 2, pp. 11-20.

Benedict XVI, Message for the 41st World of Communications Day. Children and the Media: a Challenge for Education, Vatican 2007.

Message for the 43rd World Communications Day. New technologies, New Relationships. Promoting a Culture of Respect, Dialogue and Friendship, Vatican 2009. Message for the 45th World Communications Day. Truth, Proclamation and Authenticity of Life in the Digital Age, Vatican 2011.

Message for the 47th World Communications Day. Social Networks: portals of truth and faith; new spaces for evangelization, Vatican 2013

Bosman F.G., The Incarnated Gamer: The Theophoric Quality of Games, Gaming, and Gamers, in Boundaries of Self and Reality Online: Implications of Digitally Constructed Realities, ed. J. Gackenbach, J. Bown, Cambridge 2017, pp. 187-203. Bosman F.G., Gaming and the Divine: A New Systematic Theology of Video Games, London 2019. 
Cisek S., Metoda analizy i krytyki piśmiennictwa $w$ nauce o informacji i bibliotekoznawstwie w XXI wieku, „Przegląd Biblioteczny” 2010, t. 78, nr 3, s. 273-284.

Drzewiecki P., Bezcielesność cyberprzestrzeni a sakramentalny wymiar Kościoła, „Biuletyn Edukacji Medialnej” 2008, nr 1, s. 108-115.

Drzewiecki P., Kto jest moim bliźnim w wirtualnym świecie? Teologia społeczności sieciowych w orędziach Benedykta XVI na Światowe Dni Środków Społecznego Przekazu, „Łódzkie Studia Teologiczne” 2011, t. 20, nr 1, s. 55-66.

Felczak M., Ekran i igrzyska: związki gier z biznesem i sport elektroniczny, „Kultura Współczesna" 2016, t. 90, nr 2, s. 69-77.

Franciszek, Orędzie na 53. Światowy Dzień Środków Społecznego Przekazu. „,Wszyscy tworzymy jedno" (Ef 4,25). Od wirtualnych wspólnot społecznościowych do wspólnot ludzkich, Watykan 2019.

Guttmann A., From ritual to record: The nature of modern sports, New York 2004. Jan Paweł II, Orędzie na 36. Światowy Dzień Środków Społecznego Przekazu. Internet: nowe forum głoszenia Ewangelii, Watykan 2002.

Jenny S. E., Manning R. D., Keiper M. C., Olrich T. W., Virtual(ly) athletes: where eSports fit within the definition of "Sport”, „Quest” 2017, t. 69, nr 1, s. 1-18.

Jędrasiak K., Gracz jako model uczestnika współczesnej kultury, rozprawa doktorska, Uniwersytet Łódzki, 2017.

Kuźbik P., E-sport jako kreator nowych warunków organizacyjnych w zmiennym i dynamicznym otoczeniu, „Ekonomiczne Problemy Usług” 2018, t. 131, nr 2, s. 211-220.

Myślicki M., Przepraszam, czy to sport? O profesjonalizacji e-sportów i jej skutkach, „Dziennikarstwo i Media” 2015, t. 6, s. 213-226.

Papieska Rada ds. Środków Społecznego Przekazu, Etyka w Internecie, Watykan 2002.

Papieska Rada ds. Środków Społecznego Przekazu, Kościół a Internet, Watykan 2002.

Passon M., Różyczka M., Wybrane problemy związane ze statusem zawodnika e-sportowego w świetle zbiorowego prawa pracy w Polsce, „Internetowy Przegląd Prawniczy TBSP UJ" 2018, t. 43, nr 3, s. 85-101.

Popiołek P., Prolegomena do teologii gier wideo. Ku teologicznej refleksji nad fenomenem gier cyfrowych, w: Dyskursy gier wideo, red. M. Kłosiński, K.M. Maj, Kraków 2019, s. 237-266.

Rouba R., Realny sukces wirtualnego sportu - Intel Extreme Masters-Katowice, „Przegląd Nauk Ekonomicznych” 2017, nr 27, s. 301-312.

Suits B., The Elements of Sport, w: Ethics in Sport, red. W.J. Morgan, Champaign 2007, s. 9-19. 
Bosman F.G., Van Wieringen A.L. H. M., I have faith in thee, lord: Criticism of religion and child abuse in the video game the binding of Isaac, „Religions” 2018, vol. 9, no. 4, p. 133.

S. Cisek, Metoda analizy i krytyki piśmiennictwa w nauce o informacji i bibliotekoznawstwie w XXI wieku [Methods of analysis and criticism of writing in information and library science in the 21st century, „Przegląd Biblioteczny” [Library Review] 2010, vol. 78, no. 3, pp. 273-284

P. Drzewiecki, Bezcielesność cyberprzestrzeni a sakramentalny wymiar Kościoła [The incorporeality of cyberspace and the sacramental dimension of the Church], „Biuletyn Edukacji Medialnej” 2008, no 1, p. 108-115.

P. Drzewiecki, Who is my neighbour in the virtual world? Theology of network communities in the messages of Benedict XVI for World Communications Day, „Łódzkie Studia Teologiczne” 2011, vol. 20, no. 1, pp. 55-66.

M. Felczak, Ekran i igrzyska: zwiazki gier z biznesem i sport elektroniczny [The screen and the games: the relationship between games and business and electronic sport], „Kultura Współczesna” [Contemporary Culture] 2016, vol. 90, no. 2, pp. 69-77.

Francis, Message for the 53rd World Communications Day. "We are members one of another" (Eph 4,25). From social network communities to the human community, Vatican 2019.

Guttmann A., From ritual to record: The nature of modern sports, New York 2004. John Paul II, Message for the 36th World Communications Day. Internet: A New Forum for Proclaiming the Gospel, Vatican 2002.

Jenny S. E., Manning R. D., Keiper M. C., Olrich T. W., Virtual(ly) athletes: where eSports fit within the definition of "Sport", ,Quest" 2017, vol. 69, no. 1, pp. 1-18.

K. Jędrasiak, Gracz jako model uczestnika wspótczesnej kultury [A gamer as a model participant in the contemporary culture], $\mathrm{PhD}$ dissertation, University of Lodz, Lodz 2017

P. Kuźbik, E-sport jako kreator nowych warunków organizacyjnych w zmiennym $i$ dynamicznym otoczeniu [e-Sports as a creator of new organisational conditions in a fluctuating and dynamic environment], „Economic Problems of Services” 2018, vol. 131, no. 2, pp. 211-220.

M. Myślicki, Przepraszam, czy to sport? O profesjonalizacji e-sportów i jej skutkach [Excuse me, is it sport? On the professionalisation of e-Sports and its effects], Journalism and Media 2015, vol. 6, pp. 213-226 „Dziennikarstwo i Media” 2015, t. 6, s. 213-226.

Pontifical Commission for Social Communications, Ethics in Internet, Vatican 2002 
Surówka M., Społeczność graczy komputerowych w obliczu zmian technologicznych XXI w., „Com.press” 2019, t. 2, nr 2, s. 40-58.

Wise J., The call to endless adventure: The dynamic unending ascent into God and virtual worlds, „Dialog” 2019, t. 58, nr 4, s. 307-315.

Witkowska M., Funkcjonowanie wykonawcze profesjonalnych graczy komputerowych, „Homo Ludens” 2016, t. 9, nr 1, s. 243-258.

Ziętarski M., Rosnace znaczenie przemysłu kreatywnego w Polsce na przykładzie rynku gier wideo, „Catallaxy” 2019, t. 4, nr 1, s. 73-82. 
Pontifical Commission for Social Communications, The Church and Internet, Vatican 2002

M. Passon, M. Różyczka, Wybrane problemy zwiqzane ze statusem zawodnika e-sportowego $w$ świetle zbiorowego prawa pracy $w$ Polsce [Selected problems related to the status of an e-Sports player in the light of collective labour law in Poland], TBSP UJ Internet Legal Review 2018, vol. 43, no. 3, pp. 85-101

Popiołek P., Prolegomena do teologii gier wideo. Ku teologicznej refleksji nad fenomenem gier cyfrowych [Prolegomena to the theology of video games. Towards theological reflection on the phenomenon of digital games], in: Dyskursy gier wideo [Discourses of Video Games], ed. M. Klosiński, K.M. Maj, Kraków 2019, pp. 237-266

R. Rouba, Realny sukces wirtualnego sportu - Intel Extreme Masters-Katowice [The real success of virtual sport - Intel Extreme Masters-Katowice], Review of Economic Sciences 2017, no. 27, pp. 301-312

Suits B., The Elements of Sport, w: Ethics in Sport, ed. W.J. Morgan, Champaign 2007, pp. 9-19.

M. Surówka, Społeczność graczy komputerowych w obliczu zmian technologicznych XXI [The computer gaming community under the technological changes of the 21st century], Com.press 2019, vol. 2, no. 2, pp. 40-58

Wise J., The call to endless adventure: The dynamic unending ascent into God and virtual worlds, „Dialog” 2019, vol. 58, no. 4, pp. 307-315.

M. Witkowska, Funkcjonowanie wykonawcze profesjonalnych graczy komputerowych [Executive functioning of Pro gamers], „Homo Ludens” 2016, vol. 9, no. 1, pp. 243-258; S.E. Jenny, R.D. Manning, M.C. Keiper, T.W. Olrich, Virtual(ly) athletes: where eSports fit within the definition of „Sport”, „Quest” 2017, vol. 69, no. 1, pp. 1-18.

M. Ziętarski, Rosnace znaczenie przemystu kreatywnego w Polsce na przyktadzie rynku gier wideo [The growing importance of the creative industry in Poland on the example of the video game market], „Catallaxy” 2019, vol. 4, no. 1, pp. 73-82. 